\title{
Study of Educational Technology on Modern Ideological and Political Education Min Wu
}

\author{
Wuhan Technology and Business University, Wuhan, China
}

Keywords: modern information technology; ideological and political education; challenges

\begin{abstract}
The rapid development of modern information technology has brought new opportunities both for the ideological and political education of college students, but also brought new challenges for the ideological and political education of college students. In order to deal with the opportunities and challenges, we need to re-examine and construct the system to adapt itself to the development of the ideological and political education of college students, and put the modern educational technology into practice, so as to strengthen the effectiveness of ideological and political education of college students.
\end{abstract}

\section{Introduction}

Under the background of the continuous expansion of globalization, the spurt progress of information technology, as well as the continuous deep reform and opening up, people's ideological status has showed the characteristics of diversification, complication, differentiation and personalization, which has challenged the traditional mode of ideological and political education method to constitute in a variety of ways.It makes the traditional educational methods lagged and outdated, simple and shallow, empty and fatigue with poor effectiveness, which is difficult to solve the complicated ideological and political problems in today's society. The traditional methods of ideological and political education is too simple, the trend is obviously imbalanced and increasingly complicated between the education status and the objects of ideological activities. Moreover, the phenomenon has become more obvious that the explaining abilities for the traditional ideological and political education theories are seriously out of line and are no loner suited for the developing situations of modern ideological and political education, which has been seriously restricted and affected the effectiveness of ideological and political education. Therefore, it requires to change the past type of the experienced and non-system traditional ideological and political education into the type of the scientific, systematic, standardized modern ideological and political education, so as to realize the modernization of ideological and political education.

\section{The Definition of Educational Technology}

The term of "educational technology" was a product and introduced by people in industrial society, who put the concept of engineering technology into the educational field. So far, it is still unclear that when it is introduced by a person or a group of people. Who was the first person to use the term of educational technology is still not clear. It was recorded that Franklin Bobbitt and W.W.Charters used the term of educational project in the 1920's. In 1963, Janmes D.Finn used the term of educational technology in the preface of the first publication of the technology development projects sponsored by the National Education Association (NEA). But at that time, it was mainly used for audiovisual communication (Saettler, 1990, P.M). "Educational technology was initially thought to be as a kind of technology tool. It refers to using means, media and hardware to achieve the goal of education." (Fig. 1). It tells us, the name of educational technology was evolved from the educational project and educational technology, it originally referred to the teaching tools and technology, which should be an intuitive and clear concept. According to Marx's technology thought and the generalized technology concept, combined with the characteristics of modern ideological and political education, this paper defined modern ideological and political education technology as 
follows: the so-called modern ideological and political education technology is the theory and practice in the teaching of the modern ideological and political education, under the guidance of Marx's theory, followed by the rules of modern ideological and political education, using the theory of modern education thought and modern educational technology through the process between teaching and learning, the design of the learning resources, the utilization, the management and the evaluation, so as to achieve the maximum efficiency and optimization in teaching.The essence of modern ideological and political education is the practical educational mode of ideological and political activities or behaviors to foster the "Four Haves" student as the target in the modern social conditions. Therefore, it can also be defined as the complex subject that human beings used all methods and strategies,physical tools, the operation rules as well as knowledge and skills in the activities of modern ideological and political education.

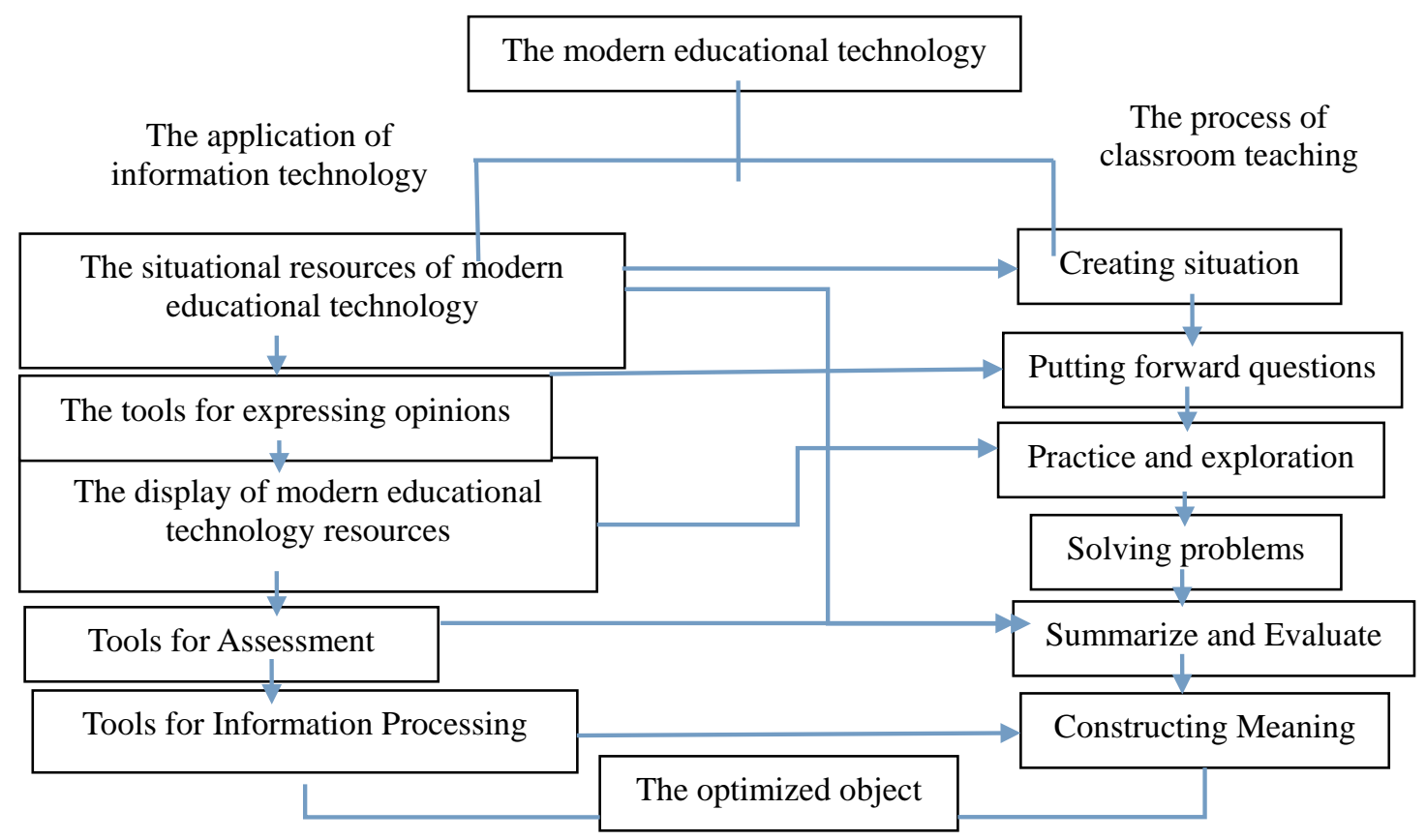

Fig. 1 Modern Educational Technology

\section{Functional Analysis on the Application of Educational Technology in Modern Ideological and Political Education}

The Application of Educational Technology Is Helpful to Improve the System of Ideological and Political Education

Compared with the other subjects, the ideological and political education has its own characteristics, its content is not limited to the classroom teaching, textbook is only a carrier of the link of education, the extension of the ideological and political education is the same as the extension of life, it pays attention to the consciousness and thinking of the students who should understand the learning contents. The overall integrity of the ideological and political education should include the integrity of ideological and political learning as well as the integrity of the students to have overall development. Under the traditional ideological and political education, teachers either use classroom teaching method to broadcast and repeatedly explain, then question the students and have the feedback, or they constantly instill the knowledge with lots of preaching, or talk, so as to achieve the goal of ideological and political education. But under the environment of modern educational technology, with the development of information technology, the means of information storage is varied such as video tape, tapes, CD-ROM, hard disk and son on, with the popularization of multimedia technology, educators can provide the perceptual materials with active images timely for the students according to the need, which can fast present, repeatedly practice and timely feedback. The interactive feature of multimedia made the frequent interactive activities 
between the computer with the student to constitute a "feedback chain", and the evaluating process can be without teachers, the evaluating result can give direct feedback to students, so that students can often analyze, summarize, sort and improve their knowledge, which can gradually form a organic whole for the political knowledge. (Fig. 2)

The modern educational technology has changed the fixed roles between the educators and the educated person in the traditional education, in educational practice, the educators are the leaders, the educated person is no longer a passive recipient, but is the constructing subject of knowledge. As the guiding theory for modern educational technology, it contains inevitable choice for history from the rise of constructivism to be gradually recognized. Constructivism holds that: the student should be as the center, in the whole process of education, the teacher plays as the role of organizer, guider and facilitator, teachers can use the elements of context, collaboration, conversation and other learning environmental elements to fully develop the initiative of students as well as the spirit of innovation, ultimately the students can achieve the purpose of constructing the current knowledge.To carry out the integration of the modern educational technology and the ideological and political education curriculum deeply is the basic way for the realization of information of the ideological and political education as soon as possible, for enhancing the level of modernization of ideological and political education, for improving the effectiveness of ideological and political education. The practitioners of modern ideological and political education must have higher information literacy as well as the ability of modern education technology, who can consciously use modern ideological and political educational technology, so as to adapt to the ideological and political educational work of the learning type society in information age.

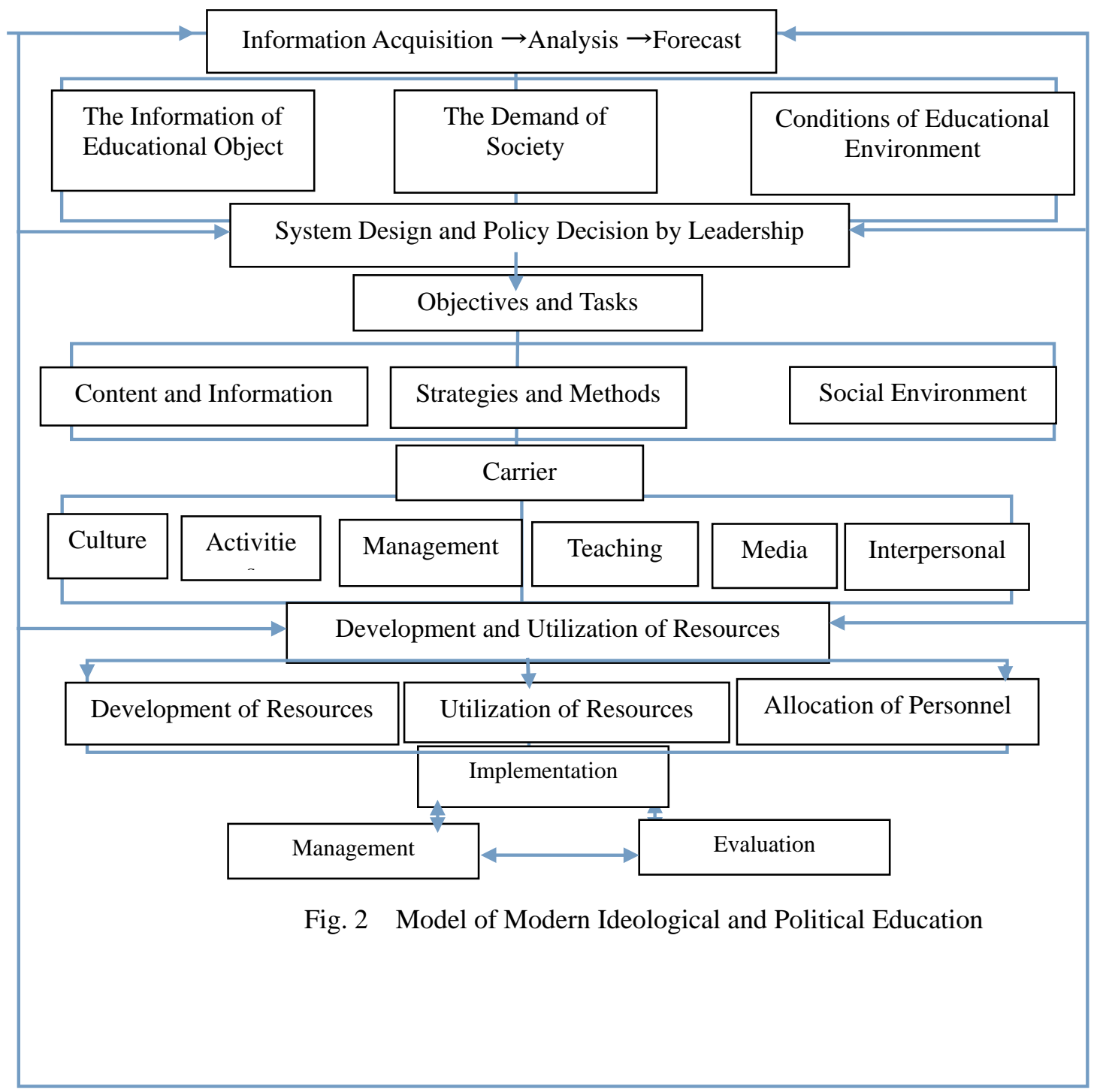


In summary, the modern ideological and political education has obtained with deep characteristics of technology, modern ideological and political educational technology as a social technical system based on the thought technology and natural technology, exists objectively in modern ideological and political educational practice, the science of modern ideological and political education should put the modern ideological and political educational technology into the research scope of the basic theory.

\section{References}

1.H.Kallen. The Education of Free Man[M].Newyork:Farrar,StrauS\&Giroux,2009:85-86.

2.Marshall,T.H.Citizenship and social class[M].London:PlutoPress,2002:16.

3. http:/ginas.blogdriver.com/ginas/5l30l4.html, educational technology,2004.

4. Tao Zhen-zong. Information technology [M]. Beijing: people's education press, 2001:62 